\section{SPRING DIARY}

BDA Seminar - Achieving high standards in infection control

Date: 19 March 2010

Venue: Hilton Manchester

Deansgate, Manchester

Website: www.bda.org

\section{DDU \& UCL Eastman Dental}

Institute CPD Conference 2010

Date: 19 March 2010

Venue: UCL Eastman Dental Institute

in Central London.

Tel: Caroline Andrews, DDU, 02072021552

Website: www.the-ddu.com/ucleastman

The Dentistry Show

12 hours' CPD available

Date: 19-20 March 2010

Venue: The NEC, Birmingham

Tel: 01926485151

Website: www.thedentistryshow.co.uk

\section{BADT}

Scottish Study Day

Verifiable CPD available to all DCPs

Date: 20 March 2010

Email: lynnebadt@hotmail.co.uk

Website: www.badt.org.uk

\section{The BDPMA management} development workshop

5 hours' CPD available

Date \& Venue: Friday 26 March Hinckley,

Hinckley Island Hotel, London

23 April, British Dental Association,

64 Wimpole Street, London

Tel: 01452886364

Email: info@bdpma.org.uk

Website: www.bdpma.org.uk

The British Society for the Study of

Prosthetic Dentistry Conference 2010:

Managing Failing Implants

Date: 27-29 March 2010

Venue: Stirling Management

Centre, Stirling

Website: www.bsspd.org
BADT

Yorkshire Regional Study Day

Verifiable CPD available to all DCPs

Date: 24 April 2010

Venue: York Marriott Hotel

Email: a.mccann@leeds.ac.uk

Website: www.badt.org.uk

\section{BSP Spring Conference:}

Conference Dinner Dance

Date: 26 April 2010

Venue: Hilton Brighton Metropole

Website: www.bsperio.org.uk

FGDP(UK) Infection Control

Workshop (London)

Date: 30 April 2010

Venue: Royal College of Surgeons

of England, London

Website: www.fgdp.org.uk

Talking Points in Dentistry.

Dates \& Venue: 4 May, Southampton,

5 May London, 6 May Watford,

11 May Falkirk, 12 May Newcasttle,

13 May Leeds, 17 May Bolton,

19 May Solihull, 20 May Bristol

Tel: Rachael 08707355385

Website: www.gsk-dental

professionals.co.uk

\section{BADT}

London Regional Study Day

Verifiable CPD available to all DCPs

Date: 15 May 2010

Email: katrina.matthews@

westminster-pct.nhs.uk

Website: www.badt.org.uk

BDA British Dental Conference

and Exhibition 2010

Date: 20-22 May 2010

Venue: Arena and Convention

Centre Liverpool

Website: www.bda.org

\section{BDA DCP CPD events}

Maximise your team's potential; Handling complaints and improving communication; Management of medical emergencies; Managing stress; Radiography and radiation protection; Law and ethics; Business planning and financial management; Record keeping

Date: June 2010 onwards

Telephone: 02075634590

Website: www.bda.org/events/training

\section{BADT}

SW Regional Study Day

Verifiable CPD available to all DCPs

Date: 20 June 2010

Email: mikeandgerry@btinternet.com

Website: www.badt.org.uk

18th International Federation of Dental Hygienists (IFDH) British Society of Dental Hygiene \& Therapy (BSDHT) International Symposium on Dental Hygiene

Up to 20 hours of CPD available

Date: 1-3 July 2010

Venue: Scottish Exhibition \& Conference Centre (SECC), Glasgow

Website: www.bsdht.org.uk

\section{UMD Professional Ltd}

Dental practice management courses

Email: fiona@umdprofessional.co.uk

Website: www.umdprofessional.co.uk
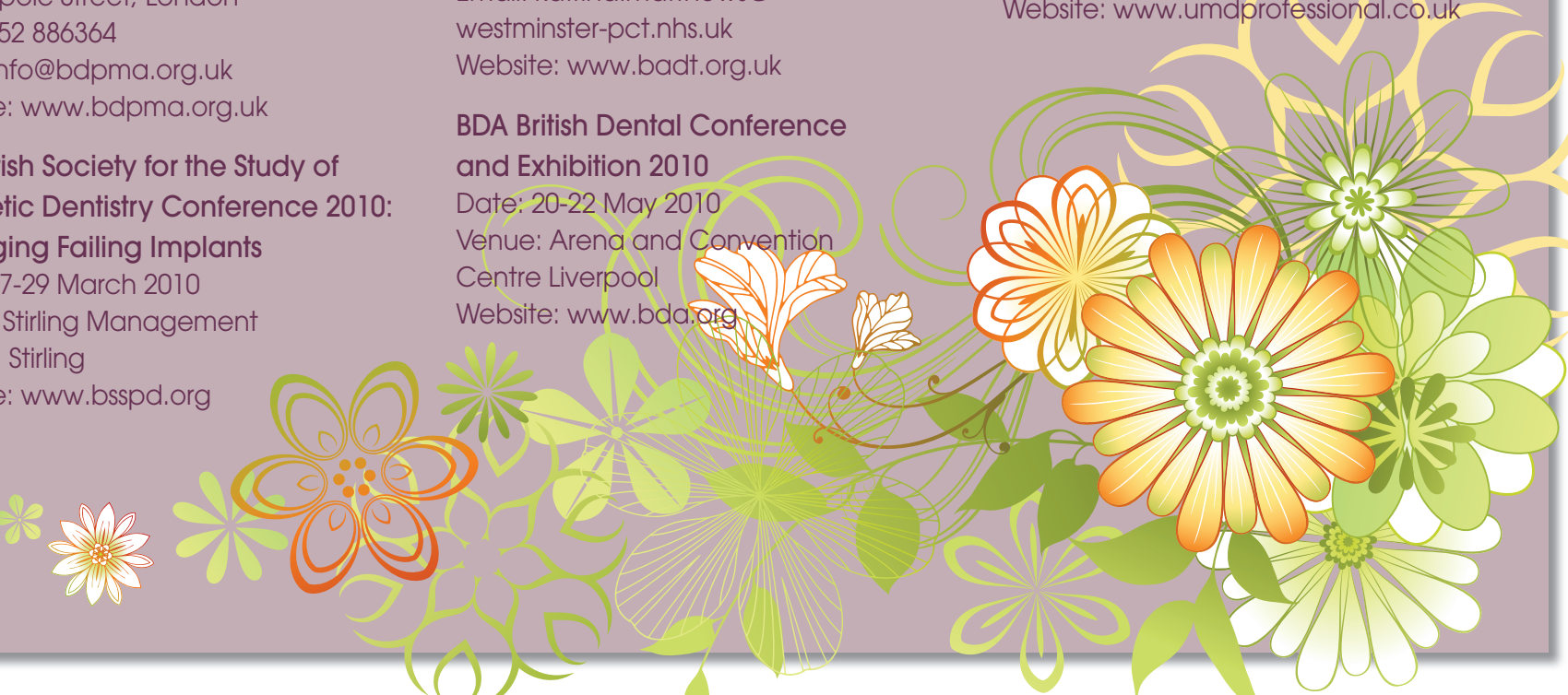

\section{VITAL DCP COURSE DIRECTORY}

An updated version of the dental care professional course directory which appeared in the summer 2009 issue of Vital will appear in the summer 2010 issue of Vital.
If you are a UK-based university, college or education provider and would like your DCP course/s to be included in this directory, please email vitaleditorial@nature.com by 9 April 2010.

Thank you. Vita 